НАУКОВИЙ ВІСНИК (1)

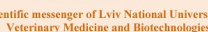
rathen 2 11) IINA Том 21 № 92
Науковий вісник Аьвівського національного університету ветеринарної медицини та біотехнодогій імені С.3. Гжицького. Серія: Харчові технологіі

Scientific Messenger of Lviv National University of Veterinary Medicine and Biotechnologies.

Series: Food Technologies

UDC 664.952/.957

\title{
The research of quality indicators of minced products based on freshwater mussel and ginko biloba powder
}

\section{A. Helikh}

Sumy National Agrarian University, Sumy, Ukraine

Article info

Received 10.09.2019

Received in revised form 09.10 .2019

Accepted 10.10.2019

Sumy National Agrarian University G. Kondratieva Str., 160, Sumy, 40021, Ukraine.

Tel.: +38-095-931-15-96

E-mail: gelihsumy@gmail.com
Helikh, A. (2019). The research of quality indicators of minced products based on freshwater mussel and ginko biloba powder. Scientific Messenger of Lviv National University of Veterinary Medicine and Biotechnologies. Series: Food Technologies, 21(92), 36-41. doi: 10.32718/nvlvetf9207

An analytical review of the literature on the ways of using hydrobionts in the technology of minced products was conducted. The possibility of using ginkgo biloba leaf powder for enrichment of minced products and their functional properties has been investigated. Based on the results of previous comprehensive studies of the physicochemical composition and safety indicators that formed the basis of the developed regulatory documentation for the semi-finished product of freshwater mussel, the possibility of using the soft body of the mussel genus Anodonta in the cuttings technology was proposed and investigated. The possibility of producing chopped freshwater mussel products with the addition of ginkgo biloba leaf powder as a functional additive is experimentally confirmed in this article. The influence of different percentages of ginkgo biloba powder on the organoleptic, functionally technological and rheological properties of the developed cutlets has been investigated. Optimal doses of use of ginkgo biloba powder in the recipe for chopped products based on freshwater mussel have been established. The differences in the plastic viscosity of different minced samples were investigated, which is explained by the different content of ginkgo biloba leaf powder supplement. The viscosity quantification in all samples indicates the rate of destruction of the structure. The output of the finished products, moisture-holding and fat-holding capacity is determined. Studies have been conducted to determine the level of active acidity of finished products. The complex of qualitative characteristics of the developed chopped products (cutlets) is investigated. The regularities of the influence of the component composition on the functional and technological characteristics of ground beef systems based on freshwater hydrobionts have been established. Investigation of the use of locally sourced, raw materials rich in nutrition in technology for minced meat products is relevant. This will allow to expand the range of existing hydrobionics products and to obtain functional products.

Key words: freshwater mussels, functional products, ginkgo biloba, minced products.

\section{Дослідження показників якості січених виробів на основі прісноводних гідробіонтів та порошку гінкго білоба}

\author{
А.О. Геліх \\ Сумський національний аграрний університет, м. Суми, Украӥна
}

Проведено аналітичний огляд літератури щодо шляхів та способів використання гідробіонтів у технологї фариевих виробів. Досліджено можливість використання порошку листя гінкго білоба для збагачення січених виробів та надання ӥм функиіональних властивостей. На основі отриманих нами результатів попередніх комплексних досліджень фізико-хімічного складу та показників безпечності, шо лягли в основу розробленої нормативної документачї на напівфабрикат з молюска прісноводного, запропоновано $i$ досліджено можливість використання м'якого тіла молюска роду Anоdonta у технології січених виробів. В даній статті експериментально підтверджено можливість виробниитва січених виробів на основі молюска прісноводного з додаванням порошку листя гінкго білоба як функціональної добавки. Досліджено вплив різної відсоткової кількості порошку гінкго білоба на органолептичні, функціонально технологічні та реологічні властивості розроблених котлет. Встановлені оптимальні дози використання порошку 
гінкго білоба у рецептурі січених виробів на основі молюска прісноводного. Досліджено відмінності в значеннях пластичної в 'язкості різних зразків фариу, щз пояснюється різним вмістом добавки порошку листя гінкго білоба. Кількісний показник ступеня в'язкості у всіх зразках показуе темп руйнування структури. Визначено вихід готової продукиії, вологоутримуючу та жироутримуючу здатність. Проведені дослідження з визначення рівня активної кислотності готових виробів. Досліджено комплекс якісних характеристик розроблених січених виробів (котлет). Встановлено закономірності впливу компонентного складу на функиіонально-технологічні характеристики фаршевих систем на основі прісноводних гідробіонтів. Дослідження напрямку використання у технології фаршевих виробів місиевих запасів продовольчої сировини, щуо багата у харчовому плані, є актуальною. Це дасть можливість розщирити асортимент виробів із гідробіонтів та отримати продукти функціонального призначення.

Ключові слова: прісноводні молюски, функціональні продукти, гінкго білоба, січені вироби.

\section{Вступ}

В останні роки попит на харчові продукти функціонального призначення значно зріс. Концепція здорового, або більш відомого науці функціонального харчування, виникла в Японії. До функціональних продуктів харчування належать продукти, що містять поживні або біологічно-активні речовини, що підвищують імунітет організму людини, поліпшують фізіологічні процеси в організмі людини. Продукти функціонального харчування допомагають запобігти хворобам і старінню організму. Сьогодення характеризується стійким погіршенням стану здоров'я населення та демографічних показників в Україні (Derzhavnyi komitet statystyky Ukrainy). Один із важливих чинників, що впливає на здоров'я населення, $є$ неповноцінне харчування (Gardner et al., 1993; Onibala, 2010; Kim, 2011; Moraes \& Pinto, 2013). За останніми даними, в регіонах нашої держави значно знизився рівень споживання повноцінних білків, не $\epsilon$ раціональною збалансованість ліпідного складу, відчутна нестача деяких мінеральних речовин та вітамінів. Дефіцит споживання повноцінного білка в Україні у 2018 році для північних регіонів становить 45,5\%; для південних районів - 34\% (Ministerstvo okhorony zdorovia Ukrainy). У зв'язку з пошуком джерел білків і розробкою нових технологій їх обробки виникла ідея створення продукції на основі прісноводних гідробіонтів та порошку гінкго білоба, що містить велику кількість біологічно активних речовин. Для комплексної переробки гідробіонтів місцевого походження, що забезпечує високий ступінь використання їхньої їстівної частини (м'якого тіла), найбільш ефективним є виробництво фаршу та різноманітних виробів на його основі. Для об'єктів промислу найбільш раціональним $\epsilon$ виготовлення фаршу із свіжовиловленої сировини. Серед місцевих прісноводних гідробіонтів існує група промислових, але недостатньо виловлюваних видів, таких як молюск прісноводний роду Anodonta. Саме цей молюск в даний час мало використовується через низький попит та відсутність промислових технологій переробки. Одним із перспективних напрямів використання прісноводного молюска $\epsilon$ виробництво формованих виробів, при якому можливе внесення у фарш різноманітних харчових добавок та компонентів 3 метою поліпшення органолептичних, структурномеханічних властивостей та збагачення харчовими волокнами. При розробці і створенні продуктів функціонального харчування необхідно знати хімічний склад, харчову цінність і спеціальні прийоми технологічної переробки сировини (Derzhavnyi komitet statystyky Ukrainy).
Молюск прісноводний - ідеальна сировина для виробництва продуктів функціонального харчування. У своєму складі він містить повноцінний білок за вмістом усіх незамінних амінокислот (Golovko et al., 2015). Аналіз жирнокислотного складу м'якого тіла прісноводних молюсків та Mytilus показує, що ліпіди його мякого тіла містять поліненасичені жирні кислоти, в тому числі $\oplus-6$ та докозопентаєнову та докозогексаєнову жирні кислоти (Golovko et al., 2016). Визначено, що в м'якому тілі прісноводних молюсків містяться цінні мікро- та макроелементи. Кількісно переважає кальцій та фосфор. У м'якому тілі міститься важливі мікроелементи: йод - 45 мкг/100 г, що майже на третину задовольняє добову потребу для дорослої людини, та селен 10 мкг/100 г. Досліджено, що за мікробіологічними показниками та показниками безпеки м'яке тіло прісноводних молюсків відповідає вимогам чинних нормативних документів (Golovko et al., 2015).

Європейський регламент зазначає, що всі твердження щодо здоров'я, які висувають до продуктів, повинні бути обгрунтовані науково. Науково обгрунтувані твердження про функціональні харчові продукти та рослинні добавки, що містять у своєму складі гінкго білоба. Встановлено, що гінкго білоба, має лікувально-профілактичну цінність i, крім того, є джерелом харчових волокон, що сприятиме покращенню структури фаршу для виготовлення різноманітної продукції. Оздоровчі і лікувальні властивості гінкго білоба добре вивчені. Активні речовини гінкго підвищують стійкість нервових клітин до дефіциту кисню та збільшують вміст енергії АТФ у корі головного мозку. Вживання порошку гінкго білоба сповільнює налипання атеросклеротичних бляшок у судинах мозку, сприяє поліпшенню слуху, зменшенню шуму у вухах та запаморочень. Гінкго стимулює покращення пам'яті, концентрацію уваги, швидкості мислення, мовні та рухові функції центральної нервової системи (Fransen et al., 2010).

Вчені Бразилії обгрунтували можливість щодо застосування нільської тилапії як основного з видів риб, що культивуються у всьому світі та в Бразилії. Метою цього дослідження було виробити рибні закуски, що містять різний рівень включення $(20,30$ та 40\%) рибного фаршу, отриманого з тилапії, та оцінити їх фізико-хімічні характеристики та огранолептичні властивості (Golovko et al., 2016).

Також, встановлена можливість отримання рибних гамбургерів з фаршу тилапії та сурімі. Це дослідження показує позитивний результат для індустріалізації та споживання потенціалу риббургерів 3 рибного фаршу, отриманого з філе кадрів. Вживання аромати- 
зованої копченої риби та сурімі спричинило значне збільшення витрат через придбання інгредієнтів. Це дослідження показує позитивний результат для індустріалізації та споживання потенціалу риббургерів 3 рибного фаршу, отриманого з філе прісноводної талапіï (Golovko et al., 2015).

Вченими Росії досліджено зразки харчового фаршу, виготовлені з прісноводної “золотої рибки”, який може бути введений у виробництво з метою переробки збиткових видів Волго-Каспійського басейну та отримання кулінарних виробів на його основі (Fransen et al., 2010).

Індонезійські дослідження мали на меті оцінити ефективність процесу перемішування рибного фаршу за допомогою індексу змішування. Використовували зразки: Oreochromis niloticus, Walleye pollack surimi та суміш обох. У цьому дослідженні було зроблено висновок, що індекс змішування може бути використаний для оцінки гелеутворюючої здатності рибного м'яса до отримання необхідної структури (Netto et al., 2014).

Вчені Республіки Корея провели вивчення фізикохімічних та сенсорних характеристик рибних фаршів, приготованої 3 різними концентраціями порошку Astragalus membranaceus (Mello et al., 2012).

Метою роботи бразильських вчених було проаналізувати умови конвективної сушки ферментативномодифікованої пасти на основі Engraulis anchoita (Mukatova et al., 2016).

Варто зазначити, що все більшою популярністю у споживачів користуються швидкозаморожені кулінарні продукти - рибні котлети, нагетси та ін. Все це дає підставу запропонувати фарш 3 молюска прісноводного як основи для створення харчових продуктів функціонального призначення. Одним із шляхів реалізації цього напрямку може бути додавання порошку гінкго білоба в фарші на основі молюска прісноводного (Gardner et al., 1993).

Метою статті є встановлення оптимальної кількості використання порошку гінкго білоба у рецептурі січених виробів на основі молюска прісноводного. Дослідити комплекс якісних характеристик розроблених січених виробів (котлет). Встановити закономірності впливу компонентного складу на функціонально-технологічні характеристики фаршевих систем на основі прісноводних гідробіонтів та порошку гінкго білоба.

\section{Матеріал і методи досліджень}

Для дослідження впливу гінкго білоба на органолептичні та реологічні властивості модельного фаршу застосовували порошок з листя гінкго білоба фірми "NUTRILITE" (у кількості 5\% до загальної маси фаршу). Як сировину для приготування рибного фаршу було використане м'яке тіло прісноводного молюска роду "Anodonta".

Фарш 3 молюска прісноводного готували шляхом тонкого подрібнення м'якого тіла молюска на м'ясорубці 3 отворами решітки 3 мм 3 подальшим промиванням у проточній воді за температури 10 $12{ }^{\circ} \mathrm{C}$. Гідромодуль фарш: вода $-1: 2$. В отримані мо- дельні фарші вносили порошок з листя гінкго білоба фірми "NUTRILITE":

- контроль (модельний фарш без добавок);

- зразок 1 (фарш $з$ порошку листя гінкго білоба фірми “NUTRILITE” 1\%),

- зразок 2 (фарш 3 порошку листя гінкго білоба фірми "NUTRILITE" 5\%),

- зразок 3 (фарш 3 порошку листя гінкго білоба фірми "NUTRILITE" 7\%). Розрахунок добавки проводили з урахуванням норм споживання згідно з рекомендаціями виробника. Рекомендоване дозування порошку листя гінкго білоба фірми “NUTRILITE” на 1 кг готової продукції становить не більше 10 г. 3 отриманого фаршу на основі молюска прісноводного була виготовлена дослідна партія котлет. Як готовий продукт були обрані котлети. Це обумовлено простотою приготування та мінімальними витратами на допоміжні компоненти.

Органолептичні показники оцінювали профільним методом з використанням 5-бальної шкали для аналізу інтенсивності окремих ознак (зовнішній вигляд, запах, колір, смак, консистенція - соковитість і щільність) і графічно зображували у вигляді профілограм.

Вимірювання в'язкості фаршів проводили на ротаційному віскозиметрі "Реотест-2" при температурі досліджуваних зразків $15 \pm 1{ }^{\circ} \mathrm{C}$. Градієнт швидкості зсуву змінювали в діапазоні від 0 до $350 \mathrm{c}^{-1}$.

Втрати маси при тепловій обробці зразків визначали методом зважування до і після термічної обробки після охолодження до температури $(25 \pm 2){ }^{\circ} \mathrm{C}$.

Масову частку вологи в дослідних зразках м'якого тіла молюсків прісноводних до і після термічної обробки визначали на приладі Чижова.

ВУЗ в м'якому тілі молюсків прісноводних до термічної обробки визначали за методом Грау-Хама.

Визначення значень активної кислотності проводилося потенціометричним методом на $\mathrm{pH}-м е т р і ~ “ \mathrm{pH}-$ $410 "$ ".

\section{Результати та їх обговорення}

Для більш повного і детального розуміння суті проведеного дослідження необхідно описати рецептурний склад та технологію виготовлення січених виробів на основі молюска прісноводного та порошку з листя гінкго білоба.

Котлети готували за рецептурою, наведеною в табл. 1.

Також враховувались втрати при змішуванні компонентів фаршу, що становили $1 \%$ та при смаженні $20 \%$. Котлети виготовлені згідно 3 технологічною схемою (рис. 1).

У процесі приготування цибулю і картоплю подрібнювалися до гомогенного стану і змішували з рибним фаршем. Далі вводилися інші компоненти (перець чорний і духмяний, сіль і меланж) і також змішувалися. Отриману масу формували в овальні форми. Маса однієї готової котлети 80-90 г. Січені напівфабрикати на основі молюска прісноводного обсмажували при температурі $140-160^{\circ} \mathrm{C}$ протягом 15 хвилин до утворення рум'яної золотистої скоринки, пропарюють протягом 10 хвилин, потім охолоджували до 
температури не вище ніж $+15^{\circ} \mathrm{C}$. Після охолодження котлети направляли на реалізацію.

Визначали вихід готової продукції, вологоутримуючу та жироутримуючу здатність.
Результати дегустаційної оцінки показали, що додавання порошку гінкго білоба у кількості $1 \%$ майже не справляє впливу на органолептичні показники продукту.

\section{Таблиця 1}

Рецептура розроблених котлет

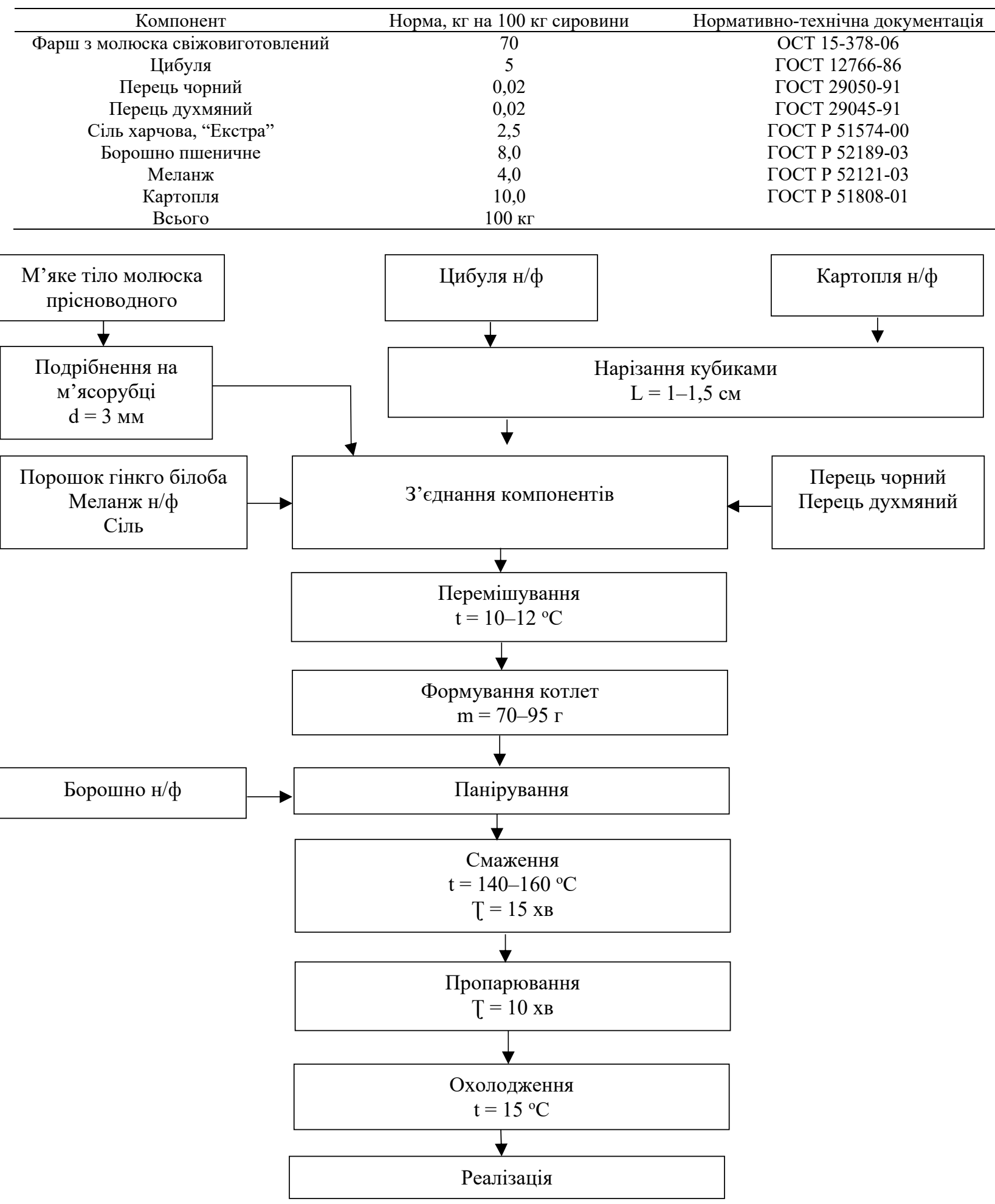

Рис. 1. Схема приготовления котлет 
Зразки з додаванням порошку гінкго білоба в кількості 5 і 7\% мають покращений зовнішній вигляд i колір. Порошок надає пружності, і продукт набуває приємного свіжого аромату. Котлети мають однорідний колір та правильну форму. Однак збільшення масової частки гінкго білоба понад $10 \%$ призводить до погіршення консистенції, зокрема котлети втрачають соковитість і пружність. Присутнє в складі котлетного фаршу м'яке тіло молюска прісноводного в поєднанні зі смаковими органічними речовинами інших компонентів обумовлює формування оригінальних смакових відчуттів. Узагальнюючи результати дегустаційних досліджень, можна констатувати, що котлети мають ніжний та характерний для прісноводної риби запах, смак, колір і зовнішній вигляд.

Фарш, в тому числі із риби та гідробіонтів $є$ складною полідисперсною системою, що складається переважно з білків, жиру і води. Додана при приготуванні фаршу вода, зв'язуючись 3 білком, утворює водно-білкову основу, яка містить екстраговані 3 м'яса водо- і солерозчинні білки, а також розчини солей. Основною вимогою технології виробництва фаршевих виробів $є$ дисперсний стан компонентів фаршу і зв'язаний стан вологи та жиру. Тому вологоутримуюча здатність є одним з найважливіших показників у технології фаршу. В результаті фізикохімічних змін, що відбуваються в процесі термічної обробки, частина води і жиру, відділяється у вигляді втрат маси. Кількість вологи і жиру, що утримана у фарші характеризує відповідно його вологоутримуючу та жироутримуючу здатність. Вологоутримуюча здатність - це різниця між вмістом вологи в фарші і кількістю вологи, що відокремилася в процесі термічної обробки. Жироутримуюча здатність фаршу визначається як різниця між вмістом жиру у фарші і кількістю жиру, що відділилися в процесі термічної обробки. Перераховані структурно-механічні показники чисельно подано у табл. 2.

\section{Таблиця 2}

Функціонально-технологічні властивості фаршу

\begin{tabular}{cccccc}
\hline Зразок & Вихід готового продукту, $\%$ & ВУЗ, $\%$ & ЖУС, $\%$ & Волога, \% & Активна кислотність \\
\hline Контроль & 75,5 & 70,6 & 72,0 & 70,9 & 6,2 \\
Зразок 1 & 76,7 & 72,3 & 72,2 & 72,1 & 6,3 \\
Зразок 2 & 78,9 & 73,9 & 72,7 & 72,9 & 6,3 \\
Зразок 3 & 78,8 & 73,7 & 72,6 & 72,7 & 6,2 \\
\hline
\end{tabular}

Введення додаткових компонентів в полідисперсну фаршеву систему, зокрема клітковини впливає на стійкість фаршевих системи. Додавання порошку гінкго білоба сприяє стабілізації фаршевих системи. Дослідження модельних фаршевих систем показали, що додавання порошку гінкго білоба у кількості 5\% сприятливо впливає на органолептичні і функціонально-технологічні властивості фаршу. Відбувається збільшення виходу, підвищується вологоутримуюча та жироутримуюча здатність продукту здатність продукту.

Розроблені фаршеві системи на основі молюска прісноводного та порошку гінкго білоба - це пластично-в'язкий продукт, який характеризується показником пластичної в'язкості. Консистенція готових січених виробів виробів безпосередньо залежить від вмісту вологи, жиру, ступеня подрібнення. Для кожного зразка були отримані значення пластичної в'язкості, що наведений в таблиці 3.

Таблиця 3

Значення реологічних параметрів

\begin{tabular}{ccccc}
\hline \multirow{2}{*}{ Назва показника } & \multirow{2}{*}{ Контроль } & \multicolumn{3}{c}{ Номер зразка } \\
\cline { 3 - 5 } & & 1 & 2 & 3 \\
\hline Пластична в'язкість, Па×с & 0,8 & 0,04 & 0,035 & 0,037 \\
\hline
\end{tabular}

Зразки № 1 та № 2 мають приблизно однакові показники пластичної в'язкості. Відмінності в значеннях модуля пружності різних зразків фаршу можна пояснити різним вмістом добавки порошку гінкго білоба. Кількісний показник ступеня в'язкості у всіх зразках показує темп руйнування структури, найменше його значення у зразка № 3 вказує на те, що руйнування структури даного зразка відбувається в меншій мірі, а найбільше - у зразка № 1.

\section{Висновки}

Таким чином, експериментальні дослідження підтверджують можливість виробництва січених виробів на основі молюска прісноводного 3 додаванням по- рошку листя гінкго білоба як функціональної добавки. Досліджено вплив різних відсоткових внесень порошку гінкго білоба на органолептичні, функціонально технологічні та реологічні властивості розроблених котлет. Встановлені оптимальні дози використання у рецептурі порошків гінкго білоба. Досліджено комплекс якісних характеристик розроблених січених виробів (котлет). Такий компонентний склад дозволить не тільки регулювати функціональнотехнологічні характеристики фаршевих систем на основі прісноводних гідробіонтів, а й збагачувати їх за рахунок коригування амінокислотного складу i присутності біологічно-активних речовин гінкго білоба. 
Перспективи подальших досліджень. Використання рослинних порошків має велику популярність. Адже саме у рослинах міститься велика кількість необхідних біологічно активних речовин. Дослідження напрямку використання у технології фаршевих виробів місцевих запасів продовольчої сировини, що багата у харчовому плані, $є$ актуальною. Це дасть можливість розширити асортимент виробів із гідробіонтів та отримати продукти функціонального призначення.

\section{References}

Derzhavnyi komitet statystyky Ukrainy [Elektronnyi resurs]. Rezhym dostupu: http://ukrstat.gov.ua (in Ukrainian).

Fransen, H.P., Pelgrom, S.M., Stewart-Knox, B., de Kaste, D., \& Verhagen, H. (2010). Assessment of health claims, content, and safety of herbal supplements containing Ginkgo biloba. Food \& Nutrition Research, 54, 1-33 doi: 10.3402/fnr.v54i0.5221.

Gardner, J.P., Skibinski, O.F., \& Bajdik, C.D. (1993). Helthy food and viability differences between the national edulis and their hybrids from two sympatric populations in S.W. England. Biol. Bull., 185, 405416.

Golovko, N., Golovko, T., \& Gelikh, A. (2015). Investigation amino-acid structure of proteins bivalve freshwater Mussels from the family Anodonta of the northern Ukraine. Eastern-European Journal of Enterprise Technologies, 5, 11(77), 10-16. doi: 10.15587/1729-4061.2015.51072.

Golovko, N., Golovko, T., \& Gelikh, A. (2015). Research qualitative composition of minerals soft body freshwater bivalve mussels of the genus Anodonta and marine counterpart - the mussels of the genus Mytilus. Progressive engineering and technology of food production enterprises, catering business and trade, 2(22), 270-278.

Golovko, N., Golovko, T., \& Gelikh, A. (2016). Research of fatty acid and mineral composition of soft body of freshwater bivalves (genus anodonta) in the northern Ukraine. Technological Audit and Production Re- serves, 3,3(29), 17-23. doi: 10.15587/23128372.2016 .71112 .

Kim, D.H. (2011). Quality characteristics of fish paste prepared with Astragalus membranaceus powder. Food Engineering Progress, 15, 362-369. http://agris.fao.org/agris-search/search.do?recordID= KR2012001510.

Mello, S.C.R.P., Freitas, M.Q., São Clemente, S.C., Franco, R.M., Nogueira, E.B., \& Freitas, D.D.G.C. (2012). Development and bacteriological, chemical and sensory characterization of fishburgers made of Tilapia minced meat and surimi. Arquivo Brasileiro de Medicina Veterinária e Zootecnia, 64(5), 1389-1397. doi: 10.1590/S0102-09352012000500041.

Ministerstvo okhorony zdorovia Ukrainy [Elektronnyi resurs]. Rezhym dostupu: http://mon.gov.ua (in Ukrainian).

Moraes, K., \& Pinto, L.A.A. (2013). Condições de secagem de uma pasta de anchoita modificada enzimaticamente na oxidação lipídica, lisina disponível e atividade antioxidante do produto Drying conditions of an enzymatic modified paste of anchovy in the lipid oxidation, available lisina and antioxidant activity of the product. Ciência Rural, 43(3), 530-536. doi: 10.1590/S0103-84782013005000008.

Mukatova, M.D., Kirichko, N.A., Romanenkova, E.N., \& Zotova, N.Yu. (2016). Development of technology for washed minced fish production from low-profit objects of fishing in the Volga-Caspian Basin. Vestnik MGTU, 19(3), 625-632. doi: 10.21443/1560-92782016-3-625-632.

Netto, J.D.P.C., de Oliveira Filho, P.R.C., LapaGuimarães, J., \& Viegas, E.M.M. (2014). Physicochemical and sensory characteristics of snack made with minced Nile tilapia. Food Science and Technology, 34(3), 591-596 doi: 10.1590/1678$457 \times .6395$.

Onibala, H. (2010). Application of mixing index (IP) for the evaluation of gel-forming ability in myofibrilprotein gels of fish pastes. Jurnal Teknologi dan Industri Pangan, 21(1), 87-90. https://journal.ipb.ac.id/index.php/jtip/article/view/241 7. 